\title{
Forest inventory and the genetic diversity of the remaining fragment of Hymenaea courbaril $L$.
}

\section{Inventário florestal e diversidade genética do fragmento remanescente de Hymenaea courbaril L.}

\author{
Marília Freitas de Vasconcelos Melo ${ }^{1}$, Sheila Valéria Alvares-Carvalho², Erica Moraes Santos de Souza ${ }^{2}$ \\ Itamara Bomfim Gois ${ }^{2}$, Robério Anastácio Ferreira ${ }^{3}$, Renata Silva-Mann ${ }^{4}$
}

\author{
${ }^{1}$ Universidade Federal de Alagoas/UFAL, Rio Largo, AL, Brasil \\ Universidade Federal de Sergipe/UFS, Programa de Pós-Graduação em Agricultura e Biodiversidade, São Cristóvão, SE, Brasil \\ 3Universidade Federal de Sergipe/UFS, Departamento de Ciências Florestais, São Cristóvão, SE, Brasil \\ ${ }^{4}$ Universidade Federal de Sergipe/UFS, Departamento de Engenharia Agronômica, São Cristóvão, SE, Brasil \\ *Corresponding author: renatamann@hotmail.com, renatamann@ufs.br \\ Received in July 4, 2018 and approved in September 24, 2018
}

\begin{abstract}
Hymenaea courbaril is a rare species in the riparian areas of the state of Sergipe, Brazil. This species is known as Brazilian cherry or Brazilian copal and it occurs in fragments of the Rainy Forest and in the transition zones between the Rainy Forest and the Caatinga Biomes. This work was carried out, in order to quantify the genetic diversity of the remaining population of Brazilian cherry, by RAPD markers. In a studied area of 100 ha in the low course of the São Francisco River, only 15 individuals were observed. The analyzed parameters were as follows: Jaccard's genetic similarity, the number of observed alleles, the number of effective alleles, the genetic diversities of Nei, the percentages of the polymorphic loci, the genetic diversities when using the Shannon index and the coancestry coefficient. There was no correlation between the genetic distances and the geographical distances. Despite the low number of individuals, high genetic diversity was observed, a fact that contributes to the development of strategies for the conservation of the species.
\end{abstract}

Index terms: Genetic conservation; seed collection; spatial correlation.

\begin{abstract}
RESUMO
Hymenaea courbaril é uma espécie rara em áreas ripárias do estado de Sergipe, Brasil. Esta espécie é conhecida como jatobá ou courbaril e ocorre em fragmentos de Mata Atlântica e em zonas de transição entre os Biomas Mata Atlântica e Caatinga. Este trabalho foi conduzido visando quantificar a diversidade genética da população remanescente de jatobá, por meio de marcadores RAPD. Na área estudada de 100 ha, na Região do Baixo São Francisco, foram observados somente 15 indivíduos. Os parâmetros analisados foram os seguintes: similaridade genética de Jaccard, número de alelos observados, número de alelos efetivos, diversidade genética de Nei, porcentagem de locos polimórficos, diversidade genética usando o índice de Shannon e coeficiente de coancestria. Não foi observada correlação entre as distâncias genéticas e as distâncias geográficas. Apesar do baixo número de indivíduos, alta variabilidade genética foi observada, fato que contribui para o desenvolvimento de estratégias para a conservação da espécie.
\end{abstract}

Termos para indexação: Conservação genética; coleção de sementes; correlação espacial.

\section{INTRODUCTION}

The São Francisco River in Brazil displays a special role for agriculture and for the ecological environment. In Sergipe, a nearby river area, there are only highly fragmented small areas of remaining forest, due to the anthropical influences (Sergipe, 2017). Species in this area have been removed without any previous management, which may now lead to the extinction of some of the specimens in this ecosystem. The Brazilian cherry species is under such dangerous conditions, with their sought-after timber and non-timber attributes over explored. The communities in developing countries strongly depend on the forest species for their subsistence, including timber for fuel, as well as for improving their nutrition, their health and their needed income from the non-timber products. The fruits of the Brazilian cherry tree can be sustenance food for many animals. These fruits can also be important for those human communities that promote one of the Food and Agriculture Organization of the United Nations-FAO strategies, for their use in feeding various autochthone inhabitants.

For biodiversity conservation, the quantification of genetic diversity remains crucial in order to outline positive strategies. The actions for the selection of individuals for their seed collections, as well as for their in situ conservation, are important, in order to minimize any genetic erosions. 
Those populations genetics studies that aim at their conservation and their use, as satisfactory areas for seed collections, are important for the production of seedlings and for the recovery efforts of the degraded areas, as well as for their genetic enrichment (Mijnsbrugge; Bischoffb; Smith, 2010; Bradbury; Krauss, 2013; Rocha et al., 2017).

The in-depth knowledge of these populations contributes greatly, in order to establish management units, for the conservation that aims at the protection of the diversities of the species. This knowledge of genetic diversity, when assessed by molecular markers, is profitable in the germplasm characterizations. The differences among the individuals and the population can be detected by genetics studies, since these estimates are essential for the definition of conservation strategies and for the selections of germplasm, which then guarantees a basic knowledge for the biodiversity distributions.

RAPD molecular markers have been used in analyzes of diversity for several species, such as for cacao (Theobroma cacao L) (Leal et al., 2008); banana (Musa spp.) (Souza et al., 2008); sugar apple (Annona squamosa L.) (Bharad; Kulwal; Bagal, 2009; Ahmad et al., 2010; Guimarães et al., 2013); Aloe ssp. (Shahira et al., 2016); Conyza bonariensis (Silva; Agostinetto; Vargas, 2016) and Abelmoschus species (Pravin; Shrikant; Venkataraman, 2018). The existence of the most recent molecular marker techniques does not underestimate the RAPD utility as a tool for the development of strategies, for the conservation of individuals and their seed collections (Santana et al., 2008; Gois, 2014a; Belarmino et al., 2017). These molecular markers are often recommended in genome studies of little-known species like Himenaea courbaril.

In Brazil, different regions suffer from the intentional and the unintentional loss of forest cover, such as in the State of Rio Grande do Sul, Southern Brazil (SOS Mata Atlântica Foundation and the National Institute for Space Research, 2015). Currently, there are ambitious efforts to restore forests, ecosystem services and biodiversity. Worldwide, the Riparian Forest Restoration Project expects to reforest 1 million ha of riparian forest in the Atlantic Rainforest in São Paulo, Brazil, with up to 800 native species (Wuethrich, 2007; NGP, 2017).

National, regional and the local activities for forest restoration will take many decades of studies. It is required that there should be long-term financing, together with strategic policies, as well as with experienced laboratory and technical staff. During these processes and efforts, it could restore new relationships between humans and forests and their use (Chazdon, 2008; Mansourian; Vallauri; Dudley, 2017; Cummings; Read; Fragoso, 2018).

From this perspective, the State of Sergipe, Brazil, has forged relationships with University Research Groups, in partnerships with the Public Ministry, the Secretary of
State Environment and Water Resources, as well as with the Brazilian Institute of the Environment and Renewable Natural Resources (IBAMA). As a consequence, it has developed recovery actions for degraded areas, mainly in the Lower São Francisco River Basin. These actions have concerned the inventory, the management and the genetic diversity characterizations of the populations of native species, as addressed in this work.

The lower course of the São Francisco River is one of the areas where vegetation has suffered from intense anthropic pressures. The area is located nearby the municipalities of Neópolis and Santana do São Francisco. The said river has a fundamental role for the sustainability of most of the agroecosystems in northeastern Brazil and it is one of the most important rivers in Brazil and South America. The river course reaches 5 states and 521 municipalities. The river's spring is located in the State of Minas Gerais and the river's mouth is in Sergipe. The river borders the State of Pernambuco to the north and it constitutes a natural border for the States of Sergipe and Alagoas; it finally flows into the Atlantic Ocean, draining an area of approximately $641,000 \mathrm{~km}^{2}$. Anthropic actions have resulted in a loss of the riverbanks, due to erosion and the irrational exploitation of the riparian forests.

Currently, the protection of the São Francisco riverbanks involves the use of vegetation, or soil bioengineering, in order to stabilize the soil, so as to avoid any further erosion of these river banks (Holanda; Rocha; Oliveira, 2008). These management procedures also include sediment removal and channels, in order to improve the flow of the river and to minimize the loss of soil, due the high speed of the water around obstructions. These actions, associated with the forest's recovery, promote the protection of the riparian vegetation, whilst at the same time, contributing to the water's quality and the maintenance of the landscape.

In those studies, when using rare species in a specific site, like in this work, even in a population of a small size, with only a few individuals, the variabilities can be present, if the size reduction of the population has only occurred recently. In such a case, the remaining individuals are actually important samples that need to be studied (Qin; Zhang; Milne, 2010; Zhao et al., 2012).

The $H$. courbaril species stands out for its database enrichment, in such a way as to define strategies on its conservation and its expansions of genetic diversity, in the areas of the Lower São Francisco River. The species is considered very rare in this region, with only 15 individuals in an area of 100 ha (Ferreira et al., 2011).

Due to the need to preserve the species, as well as to define the necessary strategies for its management and for its seed collections, together with producing a seed orchard for the progeny tests, this study was carried out 
in order to evaluate the genetic diversity of the natural population of $H$. courbaril species.

\section{MATERIAL AND METHODS}

The collections of the plant materials (leaves) were prospected from all individuals (15) in an area of 100 ha (10 $\mathrm{km} / 100 \mathrm{~m}$ ) of the riparian forest in the Baixo São Francisco area, Sergipe, Brazil (Table 1).

The DNA extractions were based on 2\% CTAB method, as described by Nienhuis et al. (1995). For the RAPD analyzes (Williams et al., 1990), the reaction mixture was composed of $2.92 \mu \mathrm{L}$ ultrapure water, $1.30 \mu \mathrm{L}$ of $10 \mathrm{X}$ buffer, $1 \mu \mathrm{L}$ of magnesium chloride $(25 \mathrm{mM}), 1.04 \mu \mathrm{L}$ dNTPs (Deoxyribonucleotide Triphosphates), $1.04 \mu$ L BSA (Bovine Serum Albumin), $0.2 \mu \mathrm{L}$ of Taq DNA Polymerase enzyme, $2.5 \mu \mathrm{L}$ of the primer and $3 \mu \mathrm{L}$ of DNA.

All individuals were tested to 20 IDT (Integrated DNA Technologies) primers. The DNA amplification program consisted of an initial temperature of $94{ }^{\circ} \mathrm{C}$ for 5 minutes, followed by 45 cycles involving temperatures of $94{ }^{\circ} \mathrm{C}$ for $1 \mathrm{~min}, 36^{\circ} \mathrm{C}$ for $2 \mathrm{~min}$ and $72^{\circ} \mathrm{C}$ for $1 \mathrm{~min}$. This was followed by $72^{\circ} \mathrm{C}$ for $5 \mathrm{~min}$. The amplification was performed in a Uniscience Biometra TPersonal Thermocycler (Caixeta et al., 2006).

The fragments were electrophoresis-separated in a $1.0 \%$ agarose gel, by using the $0.5 \mathrm{X}$ TBE (Tris-BorateEDTA) horizontal buffer system and then the gel was staining with EtBr.

In the evaluations of the electrophoresis profiles, the presence (1) and the absence ( 0 ) of bands were used in order to construct a binary matrix. Analyzes of the optimal number of polymorphic bands were performed by using the GENES Software (Cruz, 2001). The genetic similarities (Sji) were estimated by using Jaccard's similarity coefficient, using the NTSYSpc 2.1 Software (Rohlf, 2001).

For analyzes of the genetic diversity, the POPGENE Software Version 1.31 (Yeh; Yang; Boyle, 1997) was used, for employing parameters of the dominant diploid data. The number of observed alleles (na), the number of effective alleles (ne), the Nei's genetic diversity $(\hat{H})$, the percentage of polymorphic loci ( $\mathrm{P} \%)$ and the Shannon index (I) were estimated. The fixation index $(f)$, the dendrogram and the consistency of the nodes were obtained with TFPGA Genetic Data Analysis Software (Miller, 1997).

The pattern of the spatial genetic distribution of the population was evaluated with the SPAGeDi Software, Version 1.2 (Hardy;Vekemans, 2002). The values of coancestry were estimated by the Kinship Coefficient (Hardy, 2003). The standard error of the mean was obtained by Jackknife resampling, and the absence of spatial genetic distribution was tested within each distance class, by using 1,000 permutations (Hardy;Vekemans, 2002). The magnitudes were estimated by using the Sp statistic (Vekemans; Hardy, 2004): $\mathrm{Sp}=-\mathrm{blog} /\left(1-\mathrm{F}_{\mathrm{ij}}(1)\right)$, in which blog is the slope of the regression curve of the coefficients of coancestry; Fij (1) is the mean of the coercing coefficients of the first distance class (Fij); and the $\mathrm{Sp}$ values are used in order to compare the extent of the spatial genetic distribution of the individuals.

The effective population size $\left(N_{e}\right)$ was estimated according to the methodology suggested by Vencovsky (1997).

The genetic structure of the population was performed based on the Bayesian grouping model, when using the STRUCTURE software, Version 2.3.4 (Pritchard; Stephens; Donnelly, 2000; Falush et al., 2007, Hubisz et al., 2009). In this paper, the researchers have presented the results of the individuals, grouped probabilistically, according to their genotypes in the k groups (Hubisz et al., 2009). This set of parameters assumed an admixture model, by using frequencies of the correlated alleles. The simulations were performed with a burn-in of 100,000 replications, with values of $\mathrm{k}$ ranging from 2 to 7 clusters. The best $\mathrm{K}$ value was identified supported by the data according to Evanno, Regnault and Goudet (2005).

The mathematical model used by STRUCTURE was designed to sort individuals into Hardy-Weinberg populations, but the program is also frequently used to group individuals from a large number of populations into a small number of clusters that are supposed to represent the main genetic divisions within species (Kalinowski, 2011).

\section{RESULTS AND DISCUSSION}

In analyzes of the $15 \mathrm{H}$. courbaril individuals, the amplification reactions generated 161 bands, with the bands being 141 polymorphic and 20 monomorphic. The estimated polymorphism was $87.6 \%$, evidencing consistent data for the diversity analyzes. From the resampling (bootstrap), the correlation (r) was 0.99 , and the stress value (E) was 0.02 .

The high number of observed alleles $(n a=2.0)$ indicated high heterozygosity, due to the high polymorphism in the population. This information was also confirmed by the effective number of alleles $(\mathrm{ne}=1.59$ ), which displayed values of a high genetic variability. Nei's measurement of the genetic diversity $(\hat{H})$ was 0.34 and the Shannon index (I) was 0.51 . However, a high fixation index was observed $(\mathrm{f}=0.38)$.

The Sp statistic allowed for inferring that there were no spatial genetic distribution $(\mathrm{P}>0.05)$ in the studied population; i.e., the individuals presented a random distribution (Figure 1). 


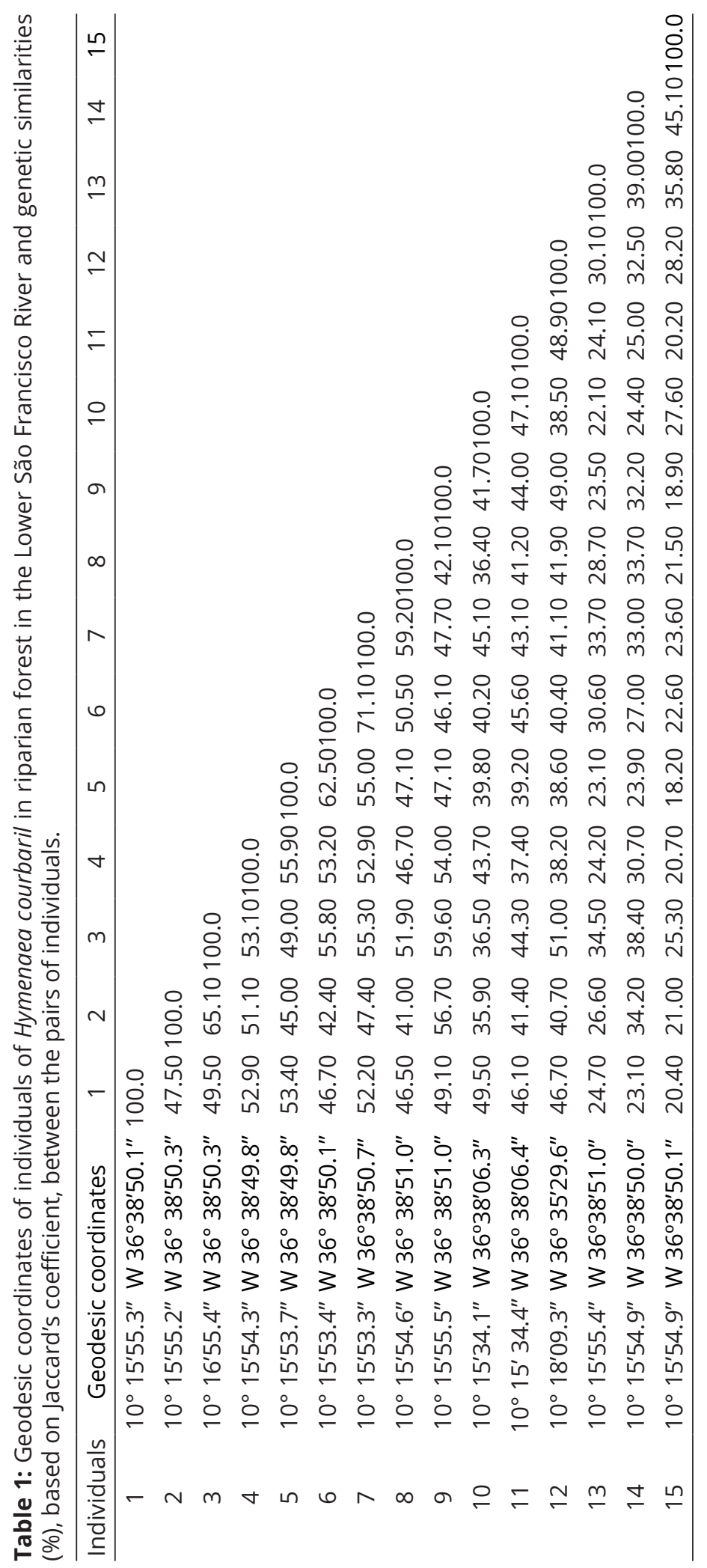




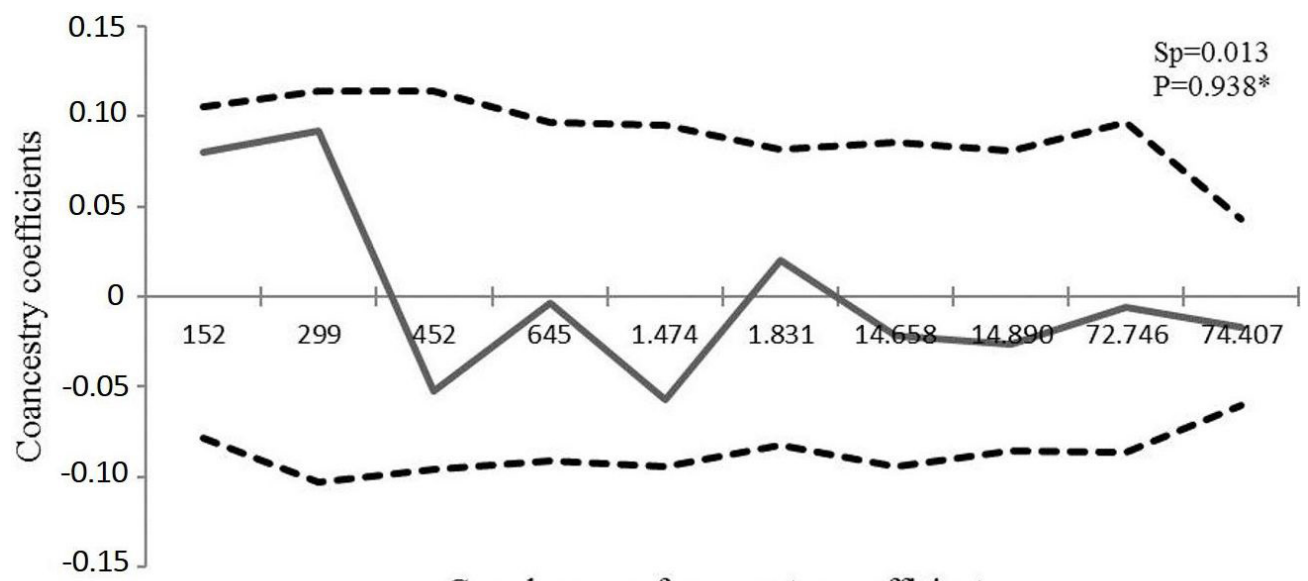

Correlogram of coancestry coefficients

Figure 1: Correlogram of the coancestry coefficients in the ten distance classes of the populations of Jatobá (Hymenaea courbaril L. var. stilbocarpa (Hayne) Lee et Lang). The traced lines indicate the limits of the error confidence interval with a $95 \%$ probability, while the solid lines indicate the coancestry coefficients that were estimated according to Loiselle et al., (1995).

The genetic similarity among the individuals varied from $18.2 \%$ to $71.1 \%$. The $\mathrm{J} 6$ and $\mathrm{J} 7$ pair presented a high similarity (71.1\%), with spatial distances of $18.95 \mathrm{~m}$; the $\mathrm{J} 5$ and $\mathrm{J} 15$ pair and the $\mathrm{J} 9$ and $\mathrm{J} 15$ pair presented the lowest similarity $(18.2 \%$ and $18.9 \%$, respectively), with spatial distances of $189.92 \mathrm{~m}$ and $127.31 \mathrm{~m}$, respectively (Table 1).

When considering a maximum distance of $50 \%$ similarity, there were three groups in the dendrogram: Group 1, individuals 1 to 9; Group 2, individuals 10,11 and 12; and Group 3, individuals 13, 14 and 15 (Figure 2). The third group presented a significant consistency $(65.25 \%)$, when compared with the other two groups. The coefficient of correlation cophenetic between genetic divergence matrix and dendrogram was equal to 0.90 , indicating that the grouping method is suitable.

The Bayesian clustering method that was implemented by the STRUCTURE software resulted in a population structure of $\Delta K=3$ (Figure 3), confirming the clustering consistency of the individuals 13,14 and 15 . However, the other two clusterings presented the individuals $1,8,10,11$ and 12 and the individuals $2,3,4,5,6,7$ and 9, respectively.

In this work, with the use of RAPD molecular markers, the genetic diversity of a population of $H$. courbaril L. was estimated and the individuals were inventoried and characterized. The number of polymorphic bands (141) favored the obtainment of consistent results in analyzes of population's genetic diversity. Other species of the family Fabaceae, Pterocarpus and Tipuana genus, produced distinct reproducible amplifications with 12 RAPD primers out of 30 primers screened. A total of
56 amplified loci were generated with 49 of them being polymorphic (Bal; Panda; Mohapatra, 2014).

The number of polymorphic bands used for the evaluation of genetic variability in forest species are variable. Rabbani, Silva-Mann and Ferreira (2012), when studying genetic diversity among 18 individuals of Genipa americana L. from the Lower São Francisco Region of Sergipe, reported a total of 86 fragments with 74 of them being polymorphic. Twenty (20) primers were used in a study of the genetic diversity of 64 sugar apple accessions (Annona squamosa L.), which resulted in 167 bands, with 48 of them being polymorphic $(28.7 \%)$. The authors related this low diversity with the number of primers tested (Guimarães et al., 2013).

When considering the number of genotypes that were used in this work, despite them being rare, there was a high degree of polymorphism, which evidenced a bias in the diversity's characterization. However, there were direct relationships between the number of bands analyzed (141) and the original similarity matrix that was obtained from the resampling (bootstrap). When the correlations reached 0.99 and the stress values were lower than 0.05 , there was an adjustment of the original matrix and the simulated matrix, therefore, these values were adequate for estimating the genetic diversity (Kruskal, 1964). This information was robust, especially when considering other studies, such as in the study of 55 individuals of mangaba (Hancornia speciosa), producing correlations (r) of 0.99 and stress values of 0.04 from their 75 fragments (Costa et al., 2011). 


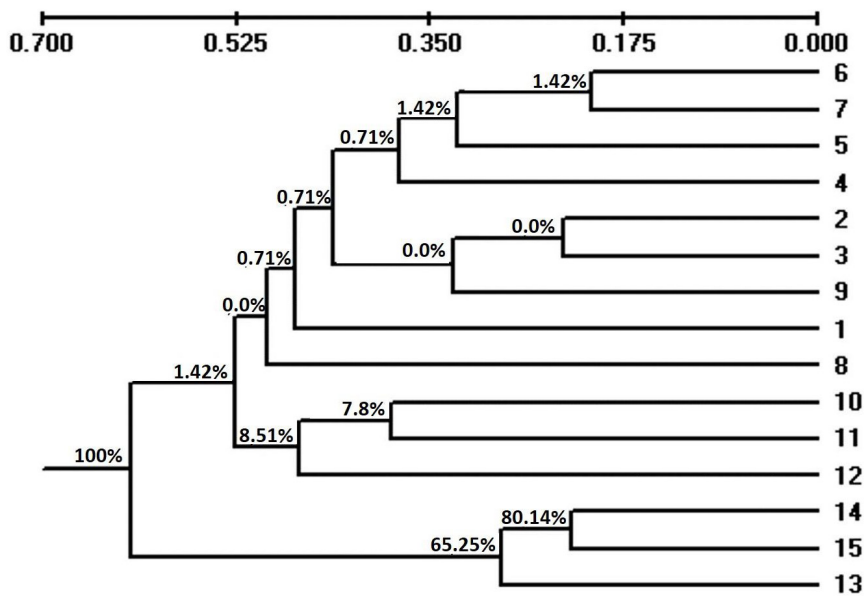

Figure 2: Dendrogram constructed by a grouping of the UPGMA (unweighted pair group method with arithmetic mean) from the genetical similarity values among the individuals of Jatobá (Hymenaea courbaril L.).
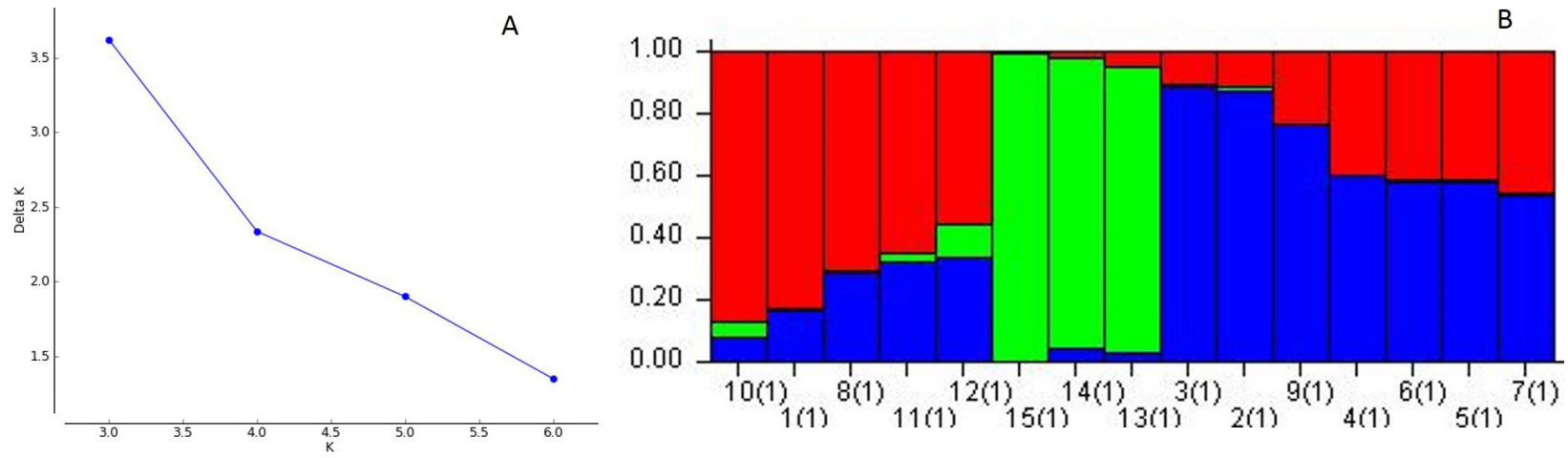

Figure 3: (A) Values of $\Delta k=3$ for the population of $H$. courbaril $L$. and their respective average probabilities that were obtained by the Bayesian approach. (B) Association of the 15 individuals of Hymenaea courbaril L.

The situations of rare occurrence of individuals of the $H$. courbaril was evidenced by the low number of individuals observed. However, such a rare occurrence could be circumvented, with analyzes of a larger number of primers (Kindt et al., 2009); i.e., with a higher amount of genome sampling.

The values that were obtained from analyzes of the Shannon index (I) confirmed the reasonable values of heterozygosity that were obtained in this study, which has allowed for inferring that the analyzed population had moderate reserves of genetic variability $(0.51)$.

The significant values of heterozygosity $(\hat{\mathrm{H}}=0.34)$ in the population confirmed the number of effective alleles that were present in the population. The populations that presented $\hat{\mathrm{H}}$ values higher or equal to 0.34 constituted reasonable genetic reserves (Oliveira, 2008). Similar results were also observed with a population of Tilia tomentosa
Moench., composed with 28 individuals, when using eight RAPD primers (Filiz et al., 2015). Likewise results were found in studies of natural populations of Ziziphus joazeiro Mart. that were located in different municipalities of the Lower São Francisco River (Gois et al., 2014b). The authors concluded that the species presented reserves of genetic variability in their populations $\left(\hat{\mathrm{H}}_{\mathrm{T}}=0.35\right)$.

Despite there being substantial genetic reserve, the fixation index (f) for the population in Sergipe were positive and significant (0.38), suggesting an excess of homozygotes in relation to the Hardy-Weinberg equilibrium (HWE). High fixation index values have also been found in other populations of $H$. courbaril. The estimatives were obtained from southwestern region of the Brazilian Amazon, in three private properties located in the municipalities of Lábrea (AM - $\mathrm{He}=0.71$ and $\mathrm{f}=$ 0.13), Capixaba ( $\mathrm{AC}-\mathrm{He}=0.72$ and $\mathrm{f}=0.20$ ) (Silva et al. 
2014), in other populations in the eastern Amazon ( $\mathrm{F}=$ 0.137) (Lacerda et al., 2008) and in the Atlantic Forest (f $=0.207)$ (Kageyama et al., 2004).

Some studies using $H$. stigonocarpa have expressed expected heterozygosity levels $(\hat{H})$ of 0.264 . These values have indicated high genetic variability. However, the high and significant fixation indexes ( $\mathrm{f}=0.106)$ have pointed to occurrences of endogamy in their populations (Defavari et al., 2009). It is important to add that these values were obtained with co-dominant markers, whereby one could expect a high degree of accuracy; however, there were not any relevant differences in their populations.

Although high levels of endogamy in $H$. courbaril are common, the low density of individuals contribute to restrict the gene flow (Silva et al., 2014; Hevroy; Moody; Krauss, 2018). The population of Sergipe presented 0.15 individuals per hectare (ind ha ${ }^{-1}$ ), a moderate value when compared to the H. courbaril populations that were located in the Amazonian regions: 0.079 ind ha $^{-1}$ (Lábrea), 0.44 ind ha $^{-1}$ (Capixaba) and 0.25 ind ha $^{-1}$ (Porto Acre) (Silva et al., 2014).

Due to the high values of the fixation index $(0.38)$ and the low density $\left(0.15\right.$ ind ha $\left.{ }^{-1}\right)$ in the population, the effective size $(\mathrm{Ne} \approx 4)$ was smaller than the sample size (26.66\%). Analyzes of the effective size of the population (Ne) showed a high degree of kinship for the individuals in the population, demonstrating that the conservation of this species in the study area requires special attention. The coefficients of coancestry $(0.079)$ were higher than expected in the families among the first cousins $(0.0625)$, but smaller in the half-sibs $(0.125)$. Consequently, the effective population size was the same as expected in the panmictic population (=4) (Carneiro et al., 2011).

The loss of these individuals is concerning, and the inbreeding may lead to an excess of homozygotes, which could then be expected in the H. courbaril population. The presence of a sub-structured population is another factor that contributes to an excess of homozygotes, suggesting an occurrence of the Wahlund effect (Waples, 2015; De Meeûs, 2018). This effect tends to reduce the frequency of heterozygotes, as consequence of the subdivision of the population; this is due to the geographical barriers of the gene flow, which are then followed by a genetic drift in the subpopulations (Garnier-Géré; Chikhi, 2008).

No spatial genetic distribution was observed $(\mathrm{P}>0.05)$ in the studied population, when using the $\mathrm{Sp}$ statistics; i.e., the individuals are randomly distributed (Figure 2). Therefore, the genetic diversity was not explained by the spatial distances, but by the possible barriers to the gene flow, which promoted the intercrossing of the related individuals. In analyzes of five fragments of the Myrcia splendens populations, random distributions of the genotypes were observed and the genetical diversities were possibly explained by the allelic flow (Brandão; Vieira; Carvalho, 2011). The genetic diversity of the individuals of Spondias mombin L. could not be explained by the geographical distances between them and genetic drift was the most reasonable explanation (Gois et al., 2014a).

The values of genetic similarity between the individuals (amplitude of $18.2 \%$ to $71.1 \%$ ) indicated the existence of considerable genetic diversity among the individuals. The $H$. courbaril individuals were clustered into three groups, when using analyzes by both Jaccard's coefficient (Figure 2) and the Bayesian method (Figure 3). Therefore, for the collection of seeds and for the seedling production which are both aimed at enriching the area, all of the individuals were important. These strategies have been considered and they have been supported by a study on Moringa oleifera L, where the estimated similarities, by the Jaccard coefficient, varied from 0.248 to 0.889 (Kumar et al., 2017). Saini et al. (2013) found a similar results. These genetics variations are satisfactory for reproduction, as well as for the development of cultivars and the assisted selection of the genetic markers in breeding programs.

A study with 24 individuals of $H$. courbaril in the State of Mato Grosso (Brazil), presented similarity values from $48 \%$ to $88 \%$ (Rocha et al., 2017). In two other studies, similarity values from $33 \%$ to $85 \%$ for Enterolobium contortisiliquum were obtained (Santana et al., 2008) and similarity values from $21 \%$ to $78 \%$ were obtained for Spondias mombin L. (Gois et al., 2014a). These values were sufficient for choosing the tree seeds. Therefore, despite the low number of individuals in the current study, the researched population has reasonable genetic diversity.

The measurements and the distributions of genetic variability in the population did not evidence any spatial genetic distribution. As a consequence, the selection of tree seeds for environmental restoration projects should be by a selection of the more genetically divergent individuals.

\section{CONCLUSIONS}

The existence of high genetic variability among the individuals of $H$. courbaril indicate that the population can be used aiming at seed collections for the restoration of the degraded areas. For the conservation of the population of $H$. courbaril, when considering the low number of individuals, the enricheciment of the area with seedlings provided from others places are very important, aiming new combinations allelics. 


\section{ACKNOWLEDGEMENTS}

The authors would like to thank the Forest Engineer, Elísio Marinho dos Santos Neto MSc, for his assistance with the logistics and with the prospecting of the plant materials.

\section{REFERENCES}

AHMAD, I. et al. ISSR and RAPD markers based the DNA fingerprinting and diversity assessment of Annona spp in South Andamans. Indian Journal of Horticulture, 67:147-151, 2010.

BAL, P.; PANDA, P.; MOHAPATRA, U. Genetic diversity and phylogenetic relationships in Pterocarpus species and its closely related genus Tipuana (Fabaceae) as revealed by RAPD and ISSR markers. Plant Science Research, 36:68-76, 2014.

BELARMINO, K. S. et al. Genetic diversity in a Poincianella pyramidalis (Tul.) L.P. Queiroz population assessed by RAPD molecular markers. Genetic Molecular Research, 16(3):1-9, 2017.

BHARAD, S. G.; KULWAL, P. L.; BAGAL, S. A. Genetic diversity study in Annona squamosa by morphological, biochemical and RAPD markers. Acta Horticulturae, 839:615-623, 2009.

BRADBURY, D.; KRAUSS, S. L. Limited impact of fragmentation and disturbance on the mating system of tuart (Eucalyptus gomphocephala, Myrtaceae): Implications for seed-source quality in ecological restoration. Australian Journal of Botany, 61:148-160, 2013.

BRANDÃO, M. M.; VIEIRA, F. D. A.; CARVALHO, D. Estrutura genética em microescala espacial de Myrcia splendens (Myrtaceae). Revista Árvore, 5:957-964, 2011.

CARNEIRO, F. S. et al. Effects of selective logging on the mating system and pollen dispersal of Hymenaea courbaril L. (Leguminosae) in the Eastern Brazilian Amazon as revealed by microsatellite analysis. Forest Ecology and Management, 262:1758-1765, 2011.

CHAZDON, R. L. Beyond deforestation: Restoring forests and ecosystem services on degraded lands. Science, 320(5882):1458-1460, 2008

COSTA, T. S. et al. Diversidade genética de acessos do banco de germoplasma de mangaba em Sergipe. Pesquisa Agropecuária Brasileira, 5:499-508, 2011.

CRUZ, C. D. Programa genes: Aplicativo computacional em genética e estatística. Viçosa: UFV, 2001, 648p.

CUMMINGS, A. R.; READ, J. M.; FRAGOSO, J. M. V. Implications of forest type and land tenure diversity for the sustainability of ecosystem services provided by northern Amazonia's multipleuse tree species. Landscape Ecology, 33:423-438, 2018.
DEFAVARI, G. R. et al. Estrutura genética espacial intrapopulacional de Hymenaea stigonocarpa Mart. Ex Hayne na Estação Ecológica de Itirapina, SP. Scientia Forestalis, 37(81):89-98, 2009.

DE MEEÛS, T. Revisiting FIS, FST, Wahlund effects, and null alleles. Journal of Heredity, 109(4):446-456, 2018.

EVANNO, G.; REGNAULT, S.; GOUDET, J. Detecting the number of clusters of individuals using the software structure. A simulation study. Molecular Ecology, 14:2611-2620, 2005.

FALUSH, D.; STEPHENS, M.; PRITCHARD, J. K. Inference of population structure using multilocus genotype data: Dominant markers and null alleles. Molecular Ecology Notes, 7(4):574-578, 2007.

FERREIRA, R. A. et al. As áreas ciliares na região do Baixo São Francisco: Processo de ocupação e recuperação. In: LUCAS, T. A. A.; AGUIAR NETTO, A. de O. (Orgs). Águas do São Francisco. São Cristóvão. Editora UFS. 2011. 312p.

FILIZ, E. et al. Assessment of genetic variations of silver lime (Tilia tomentosa Moench.) by RAPD markers in urban and forest ecosystems. Biotechnology \& Biotechnological Equipment, 29:631-636, 2015.

FUNDAÇÃO SOS MATA ATLÂNTICA AND INSTITUTO NACIONAL DE PESQUISAS ESPACIAIS (INPE). Atlas dos Remanescentes Florestais da Mata Atlântica Período 2013-2014, 2015. Available in: <http://mapas.sosma.org.br/site_media/ download/atlas_2013-2014_relatorio_tecnico_2015.pdf> Access in: September, 20, 2017.

GARNIER-GE'RE', P. H.; CHIKHI, L. Genetics of large populations and association studies. In: Encyclopedia of Life Sciences. John Wiley \& Sons Ltd, Chichester, 2008. Available in:< http://www.els.net/. Access in: May, 19, 2018.

GOIS, I. B. et al. Diversidade genética entre indivíduos de Spondias lutea L. procedentes do baixo São Francisco sergipano, por meio de marcadores RAPD. Revista Árvore, 2:261-270, 2014a.

GOIS, I. B. et al. Variabilidade genética em populações naturais de Ziziphus joazeiro Mart, por meio de marcadores moleculares RAPD. Revista Árvore, 4:621-630, 2014b.

GUIMARÃES, J. F. R. et al. Genetic diversity in sugar apple (Annona squamosa $\mathrm{L}$ ) by using RAPD markers. Revista Ceres, 3:428431, 2013

HARDY, O. J.; VEKEMANS, X. SPAGEDi: A versatile computer program to analyze spatial genetic structure at the individual or population levels. Molecular Ecology Notes, 2:618-620, 2002 
HARDY, O. J. Estimation of pairwise relatedness between individuals and characterization of isolation-by-distance processes using dominant genetic markers. Molecular Ecology, 12:1577-1588, 2003.

HEVROY, T. H.; MOODY, M. L.; KRAUSS, S. L. Population genetic analysis reveals barriers and corridors for gene flow within and among riparian populations of a rare plant. AoB Plants, 10(1):1-12, 2018.

HOLANDA, F. S. R.; ROCHA, I. P.; OLIVEIRA, V. S. Estabilização de taludes marginais com técnicas de bioengenharia de solos no Baixo São Francisco. Revista Brasileira de Engenharia Agrícola e Ambiental, 6:570-575, 2008.

HUBISZ, M. J. et al. Inferring weak population structure with the assistance of sample group information. Molecular Ecology Resources, 5:1322-1332, 2009.

KINDT, R. et al. Molecular Markers for Tropical Trees: Statistical Analysis of Dominant. World Agroforestry Centre, 2009, 172p.

KUMAR, P. et al. Molecular fingerprinting and assessment of genetic variations among advanced breeding lines of Moringa oleifera L. by using seed proteins, RAPD and Cytochrome P450 based markers. South African Journal of Botany, 111:60-67, 2017.

KRUSKAL, J. B. Multidimensional scaling by optimizing a goodness of fit to a non-metric hypothesis. Psychometrika, 29:1-27, 1964.

KAGEYAMA, P. Y. et al. Diversidade genética em espécies arbóreas tropicais de diferentes estágios sucessionais por marcadores genéticos. Scientia Forestalis, 64:93-107, 2003.

KALINOWSKI, S. T. The computer program STRUCTURE does not reliably identify the main genetic clusters within species: Simulations and implications for human population structure. Heredity, 106(4):625-632, 2011.

LACERDA, A. E. B. et. al. Effects of reduced impact logging on genetic diversity and spatial genetic structure of a Hymenaea courbaril population in the Brazilian Amazon Forest. Forest Ecology and Management, 255:1034-1043, 2008.

LEAL, J. B. Diversidade genética entre acessos de cacau de fazendas e de banco de germoplasma na Bahia. Pesquisa Agropecuária Brasileira, 43:851-858, 2008.

LOISELLE, B. A. et al. Spatial genetic structure of a tropical understory shrub, Psychotria officinalis (Rubiaceae). American Journal of Botany, 11:1420-1425, 1995.

MANSOURIAN, S.; VALLAURI, D.; DUDLEY, N. Forest Landscape Restoration: Progress in the Last Decade and Remaining Challenges. Ecological Restoration, 35:281-288, 2017.
MIJNSBRUGGEA, K. V.; BISCHOFFB, A.; SMITH, B. A question of origin: Where and how to collect seed for ecological restoration. Basic and Applied Ecology, 11:300-311, 2010.

MILLER, M. P. Tools for population genetics analyses (TFPGA): A Windows program for the analysis of allozyme and molecular population genetic data 1.3. Northern Arizona University, Flagstaff, 1997. 33p.

NGP, NEW GENERATION PLANTATIONS. Plantations for people, planet and prosperity: 10 years of the New Generation Plantations platform 2007-2017. Writer: Barney Jeffries; Coordination: Luis Neves Silva. WWF. 2017. 104p.

NIENHUIS, J. et al. Genetic relationships among cultivars and lines of lima bean (Phaseolus lunatus L) as measured by RAPD markers. Journal of the American Society for Horticultural Science, 2:300-306, 1995.

OLIVEIRA, D. A. et al. Variabilidade genética de populações de fava d'anta (Dimorphandra mollis) da região norte do Estado de Minas Gerais. Revista Árvore, 2:355-363, 2008.

PRAVIN, P.; SHRIKANT, S.; VENKATARAMAN, B. K. Species relationships among wild and cultivated Abelmoschus Medik., (Malvaceae) species as reveled by molecular markers. International Journal of Life Sciences, 6(1):4959, 2018.

PRITCHARD, J. K.; STEPHENS, M.; DONNELLY, P. Inference of population structure using multilocus genotype data. Genetics, 155(2):945-59, 2000.

QIN, Q.; ZHANG, C.; MILNE, R. Population genetics and breeding system of Tupistra pingbianensis (Liliaceae), a naturally rare plant endemic to SW China. Journal of Systematics and Evolution, 48:47-57, 2010.

RABBANI, A. R. C.; SILVA-MANN, R.; FERREIRA, R. A. Variabilidade genética de Genipa americana $\mathrm{L}$. pertencente ao baixo curso do rio São Francisco. Revista Árvore, 36:401-409, 2012.

ROCHA, V. D. et al. Genetic diversity among Hymenaea courbaril L. genotypes naturally occurring in the north of Mato Grosso State, Brazil. Genetics and Molecular Research, 16(3):1-9, 2017.

ROHLF, F. J. Numerical taxonomy and multivariate analysis system. New York Version 2.1, Department of Ecology and Evolution, State University of New York, 2001, 44p.

SANTANA, G. C. et al. Diversidade genética de enterolobium contortisiliquum (vell) morong no baixo Rio São Francisco, por meio de marcadores RAPD. Revista Árvore, 3:427433, 2008. 
SAINI, R. K. et al. Genetic diversity of commercially grown Moringa oleifera Lam. cultivars from India by RAPD, ISSR and cytochrome P450-based markers. Plant Systematics and Evolution, 299:1205-1213, 2013.

SERGIPE. Secretaria de estado do meio ambiente e dos recursos hídricos. Unidades de Conservação [Online] 2017. Available in: <http://www.semarh.se.gov.br/biodiversidade/modules/ tinyd0/index.php?id=11>. Access in: March, 28, 2017.

SHAHIRA, M. et al. Use of Random Amplified Polymorphic DNA (RAPD) technique to study the genetic diversity of eight Aloe species. Planta Medica, 82:1381-1386, 2016.

SILVA, D. R. O.; AGOSTINETTO, D.; VARGAS, L. Molecular characterization of Hairy fleabane using RAPD. Planta Daninha, 34:433-442, 2016.

SILVA, S. M. M. et al. Parâmetros genéticos para a conservação de Hymenaea courbaril L. na Amazônia Sul-Ocidental. Ciência Florestal, 24(1):87-95, 2014.

SOUZA, C. M. P. et al. Avaliação da dissimilaridade genética em genótipos de bananeira (Musa spp) via marcadores RAPD. Revista Brasileira de Fruticultura, 30:419-424, 2008.
VEKEMANS, X.; HARDY, O. J. New insights from fine-scale spatial genetic structure analyses in plant populations. Molecular Ecology, 13:921-935, 2004.

VENCOVSKY, R. Biometrical approaches for molecular markers: Estimation of effective population size. In: International Workshop on Agricultural Biotechnology, p.233-234, 1997.

WAPLES, R. S. Testing for Hardy-Weinberg Proportions: Have we lost the plot? Journal of heredity, 106:1-19, 2015.

WILLIAMS, J. G. K. et al. DNA polymorphisms amplified by arbitrary primers are useful as genetic markers. Nucleic Acids Research, 18:6531-6535, 1990.

WUETHRICH, B. Biodiversity reconstructing Brazil's Atlantic rainforest. Science, 5815:1070-1072, 2007.

YEH, F. C.; YANG, R. C.; BOYLE, T. POPGENE: Software Microsoft Window-based freeware for population genetic analysis 1.21, University of Alberta, Edmonton, 1997, 29p.

ZHAO, X. et al. High genetic diversity and low differentiation of Michelia coriacea (Magnoliaceae), a critically endangered endemic in southeast Yunnan, China. International Journal of Molecular Sciences, 13:4396-4411, 2012. 